\title{
Global warming in Amazonia: Impacts and Mitigation
}

\author{
Philip Martin FEARNSIDE ${ }^{1}$
}

\begin{abstract}
Global warming has potentially catastrophic impacts in Amazonia, while at the same time maintenance of the Amazon forest offers one of the most valuable and cost-effective options for mitigating climate change. We know that the El Niño phenomenon, caused by temperature oscillations of surface water in the Pacific, has serious impacts in Amazonia, causing droughts and forest fires (as in 1997-1998). Temperature oscillations in the Atlantic also provoke severe droughts (as in 2005). We also know that Amazonian trees die both from fires and from water stress under hot, dry conditions. In addition, water recycled through the forest provides rainfall that maintains climatic conditions appropriate for tropical forest, especially in the dry season. What we need to know quickly, through intensified research, includes progress in representing El Niño and the Atlantic oscillations in climatic models, representation of biotic feedbacks in models used for decision-making about global warming, and narrowing the range of estimating climate sensitivity to reduce uncertainty about the probability of very severe impacts. Items that need to be negotiated include the definition of "dangerous" climate change, with the corresponding maximum levels of greenhouse gases in the atmosphere. Mitigation of global warming must include maintaining the Amazon forest, which has benefits for combating global warming from two separate roles: cutting the flow the emissions of carbon each year from the rapid pace of deforestation, and avoiding emission of the stock of carbon in the remaining forest that can be released by various ways, including climate change itself. Barriers to rewarding forest maintenance include the need for financial rewards for both of these roles. Other needs are for continued reduction of uncertainty regarding emissions and deforestation processes, as well as agreement on the basis of carbon accounting. As one of the countries most subject to impacts of climate change, Brazil must assume the leadership in fighting global warming.
\end{abstract}

KEYwORDS: Carbon, Climate change, Deforestation, Environmental services, Global warming, Greenhouse effect

\section{Aquecimento Global na Amazônia: Impactos e Mitigação}

\section{RESUMO}

O aquecimento global tem impactos potencialmente catastróficos na Amazônia, e, ao mesmo tempo, a manutenção da floresta amazônica oferece uma das opçóes mais valiosas e baratas para mitigar as mudanças climáticas. Nós sabemos que o fenômeno de El Nińo, causado por uma oscilação da temperatura da superfície da água no Pacífico, tem impactos sérios na Amazônia, causando secas e incêndios florestais, como aconteceram em 1997-1998. Oscilaçôes de temperatura no Attântico também provocam secas severas, como em 2005. Nós também sabemos que árvores amazônicas morrem, tanto do fogo como do estresse hídrico sob condiçôes quentes e secas. Além disso, a água reciclada pela floresta fornece chuva que mantém as condiçóes climáticas apropriadas para floresta tropical, especialmente durante a estação seca. O que nós precisamos saber com urgência, por meio de pesquisa intensificada, inclui como representar melhor o El Niño e as oscilaçóes no Atlântico, nos modelos climáticos, como representar as retroalimentaçóes bióticas nos modelos usados para tomada de decisão sobre o efeito estufa, e um estreitamento da gama das estimativas da sensitividade climática (para reduzir a incerteza sobre a probabilidade de impactos muito severos). Assuntos que precisam ser negociados incluem a definição de mudança de clima "perigosa", com os correspondentes níveis máximos das concentraçôes de gases de estufa na atmosfera. Mitigação do efeito estufa tem que incluir a manutenção da floresta amazônica, o que traz benefícios para o combate ao efeito estufa por meio de dois papéis separados:

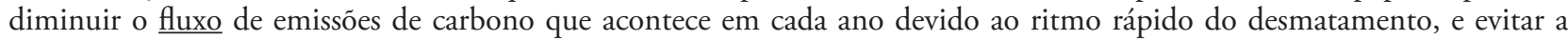
emissão do estoque de carbono na floresta restante que pode ser liberada de várias maneiras, inclusive por causa da própria mudança climática. Barreiras impedindo a recompensação da manutenção de floresta incluem a necessidade por recompensas financeiras para ambos estes papéis. Outras necessidades são continuar a redução da incerteza relativo às emissões e ao processo de desmatamento, assim como também um acordo sobre a base da contabilidade do carbono. Por ser um dos países mais sujeito aos impactos da mudança climática, o Brasil tem que assumir a liderança na luta contra o aquecimento global.

PALAVRAS-CHAVE: Aquecimento global, Carbono, Desmatamento, Efeito estufa, Mudança climática, Serviços Ambientais

1 Instituto Nacional de Pesquisas da Amazônia - INPA

C.P. 478. CEP 69.011-970 Manaus-Amazonas. E-mail: pmfearn@inpa.gov.br 


\section{I.) THE ROLE OF AMAZON FOREST IN GLOBAL WARMING}

Climate change is a threat to the Amazon forest and loss of the forest is a threat to the climate. Land-use change in Amazonia produces globally significant emissions of greenhouse gases such as carbon dioxide, methane and nitrous oxide (Fearnside, 2007a, 2008a, 2008b). Because each hectare of deforestation has a significant net emission, reducing deforestation rates represents an avoided impact. The potential value of this avoided impact is much larger than the value that can be earned through traditional land uses such as the sale of timber and cattle, which are based on destruction of the forest. Avoided deforestation is a means of transforming the value of the forest's environmental services into a cash flow that can be used to maintain both the forest and the human population that defends it. Avoiding emissions of greenhouse gases represents the environmental service that it is closest to becoming a significant source of income in Amazonia, while maintaining biodiversity and water cycling are potential sources of value over the long term (Fearnside, 2008c). Use of the value of the forest's role in maintaining the global carbon balance depends on a reliable quantification of the emissions caused by deforestation.

Global warming is a grave threat to the world as a whole, and Brazil, including Amazonia, is one of the places expected to suffer the most severe impacts if emissions of greenhouse gases continue unchecked. It is therefore necessary to reduce the total global emission from all sources, whether or not the sources count as "direct human-induced emissions" that are the responsibility of any particular country (Allen et al., 2009; Meinshausen et al., 2009).

\section{II.) IMPACTS OF GLOBAL WARMING IN AMAZONIA}

\section{A.) WHAT WE KNOW}

\section{1.) El Niño impacts in Amazonia}

The key question for Amazonia is the future of El Niño. The recent Fourth Assessment Report of the Intergovernmental Panel on Climate Change (IPCC) finds agreement among models on an increase in "El Niño-like conditions" with continued global warming (Meehl et al., 2007, pp. 779-780). This refers to warm water in the Pacific Ocean, which triggers El Niño. However, the report finds no agreement among the models on El Nińo itself, meaning the droughts and floods at different locations around the world. El Niño is very difficult to model and should obviously be a top priority. It is hard to get all the symptoms happening simultaneously in a model, with rain on the coast of Peru, drought in Amazonia, floods in southern Brazil, drought in Ethiopia and Borneo, etc. Our problem in Amazonia is that we know from direct experience that whenever there is warm water in the Pacific we have droughts and forest fires in Amazonia. If a climate model shows the Pacific warming up and nothing happening in Amazonia, it means that there is something missing from the model, not that we are safer here. The link between warm water in the Pacific Ocean and droughts and forest fires in Amazonia is demonstrated by the complete coincidence of these events in Amazonia with past "El Niño-like conditions," for example in 2003, 1997 and 1982. El Niño occurrence and impact is therefore an anchor in reality - it derives from direct observation and does not depend on the results of climate models.

\section{2.) Atlantic oscillation}

A previously unappreciated climatic threat became apparent in 2005 when a devastating drought struck Amazonia. Streamflows in tributaries on the south side of the Amazon River were so low that boats could not navigate the rivers and riverside communities were isolated from hospitals and other essential services. Forest fires burned in Acre and in neighboring parts of the state of Amazonas, an unprecedented event (Brown et al., 2006; Vasconcelos and Brown, 2007). The forest lost biomass through stunted growth and increased tree mortality (Phillips et al., 2009). The year 2005 was not an El Niño year; rather than warm water in the Pacific there was warm water in the southern part of the North Atlantic and colder-than-usual water in the northern part of the South Atlantic. The warm water in the North Atlantic gave energy to Hurricane Katrina that struck New Orleans that year. It also contributed to the Amazon drought by causing more air to rise when the Intertropical Convergence Zone (ITCZ) reached the area of warm water. The air at the ITCZ rises to an altitude of approximately $1800 \mathrm{~m}$, divides into northward and southward flows, and then moves towards the poles by approximately $30^{\circ}$ of latitude before descending to ground level and returning towards the equator at low altitude, thus forming the Hadley cell. When the air rises, its moisture content condenses and falls as rain, and when the air later descends to ground level it is dry and desiccates the area where it comes to earth. With more hot, humid air rising at the ITCZ in 2005 , there was also more cold, dry air coming down $30^{\circ}$ farther south. With the temperature gradient between warm water in the North Atlantic and cold in the South Atlantic, the ITCZ was drawn further north than usual, and at the time of year when the seasonal movement of the ITCZ was near its northern extreme, dry air was descending over the headwaters of the Amazon tributaries on the southern side of the basin (e.g,, Fearnside, 2006a; Marengo et al., 2008).

The warm water in the North Atlantic in 2005 was the combined result of several factors. One was the Atlantic Multi-decadal Oscillation (AMO), which produces warmer- 
than-average water in this area at approximately 40 -year intervals. However, this oscillation explains no more than $11 \%$ of the anomalous temperature in 2005 , whereas $50 \%$ of the temperature increase could be directly attributed to global warming (Trenberth and Shea, 2006). There was also a 22\% indirect contribution from global warming from the remains of an El Niño period in the preceding years. In addition, the reduction of industrial air pollution in Europe and North America resulted in less shielding of this area of ocean by aerosols (Cox et al., 2008).

The north-south temperature gradient in the Atlantic is significantly correlated with rainfall in the southwestern portion of Amazonia, and in 2005 both the Atlantic gradient and drought in southwestern Amazonia were at extreme levels (Cox et al., 2008). Results from the Hadley Centre model indicate a tremendous increase in the magnitude of the Atlantic temperature gradient and associated Amazon droughts if greenhouse-gas emissions continue their current path (Cox et al., 2008). The simulation results indicate that the probability of a drought as severe as that of 2005 was $5 \%$ (1 year in 20) in 2005, but this would rise to $50 \%$ (1 year in 2) by 2025 and $90 \%$ ( 9 years in 10 ) by 2060 . The probability of these droughts explodes if atmospheric $\mathrm{CO}_{2}$ exceeds 400 ppmv, a level only slightly higher than the 2009 level of 387 ppmv. Atmospheric $\mathrm{CO}_{2}$ concentrations are rising at approximately $2.6 \mathrm{ppmv} / \mathrm{year}$.

\section{3.) Forest dieback}

The Amazon forest is quite vulnerable to climate changes in the direction predicted to result from continued global warming: higher temperatures combined with less rainfall, including longer dry seasons. When temperatures are higher, trees need more water just to survive. Trees in standing forest can be killed due to climate variability in today's climate, as occurred in the 1997-1998 El Niño drought (caused by warm water in the Pacific Ocean) and in the severe drought in 2005 (caused by warm water in the Atlantic). In addition to trees essentially dying of thirst during droughts, the greater chance of forest fires starting and spreading greatly increases the risk to the forest were the climate to change as projected (Nepstad et al., 1999, 2001). Tropical forests are more susceptible to fire than are other vegetation types because forest fires have been so rare over the last millennia that the tropical-forest trees did not need to evolve defenses against fire. Amazonian trees have thin bark, and when fires occur the cambium is heated under the bark at the base of the trunk, and the trees die. Trees in other biomes, such as the cerrado, have thick bark and resist fire.

Various lines of evidence indicate that Amazonian forest can succumb to these changes. In the INPA/STRI Biological Dynamics of Forest Fragments Project north of Manaus, over
65,000 trees have been tagged and monitored; the study shows clearly that trees die with much greater frequency near forest edges, where microclimatic conditions are hotter and drier than in the interior of a continuous forest (Nascimento and Laurance, 2004; Laurance et al., 2006). The same result has been confirmed near Santarém by the "Seca Floresta" Project, which is a part of the Large-Scale Atmosphere Biosphere Experiment in Amazonia (LBA). Plastic sheeting was installed to intercept $60 \%$ of the throughfall in the forest over a onehectare plot, and tree mortality greatly increased (Nepstad $e t$ al., 2007). Both studies found that large trees are the first to die, thus both increasing the release of carbon and allowing canopy opening to further dry the forest microclimate.

Unfortunately, Brazil's official positions in this area have been to deny the problem: when the IPCC released its report on impacts in April 2007, the Folha de São Paulo reported that "Yesterday [5 April 2007] the Folha de São Paulo [newspaper] found that the Brazilian delegation [to the Intergovernmental Panel on Climate Change meeting in Brussels] objected to the final text of the summary mentioning savannization of Amazonia caused by global warming" (Folha de São Paulo, 2007). However, no less than four chapters of the IPCC report highlight the danger of savannization in Amazonia and the summary for policy makers was approved with the statement that "By mid century, increases in temperature and associated decreases in soil water are projected to lead to gradual replacement of tropical forest by savanna in eastern Amazonia" (IPCC, 2007a). The Brazilian delegation's position is symptomatic. Just as US President George W. Bush denied the very existence of global warming, thereby freeing himself of any onus to do something about the problem, the Brazilian delegation's efforts to avert official recognition of the danger of savannization in Amazonia has the effect of forestalling the need for the Brazilian government to confront the problem, including containing deforestation and reducing greenhousegas emissions.

\section{4.) Evapotranspiration and rainfall}

Simulations indicate that if over $40 \%$ of the original forest in Amazonia were cut and converted to cattle pasture or soybeans, the rainfall in eastern Amazonia would decline precipitously, especially during the dry season (Sampaio et al., 2007). These changes in precipitation could lead to degradation of the remainder of the forest in this area. Whether or not $40 \%$ deforestation is the "tipping point," or threshold, the existence of such a threshold has long been suspected and constitutes a strong argument for stopping deforestation (Fearnside, 1985, 1997). As of 2008 a total of $18 \%$ of the originally forested area in the Legal Amazon region had been cleared (Brazil, INPE, 2009). However, no safe level of deforestation exists below which there is no risk. Rather than a single "tipping point," every tree that falls increases 
slightly the probability that irreversible feedbacks will be set in motion and destroy the remaining forest. This is a risk that Brazil and the world can ill afford.

\section{B.) WHAT WE NEED TO KNOW}

\section{1.) Modeling El Niño}

Although our knowledge contains various gaps, it is important to emphasize that this fact does not represent a valid reason for any delay in actions to fight global warming. On the contrary, the existence of uncertainties means that we should be reducing emissions of greenhouse gases even more in order to insure that the worst-case scenarios do not become reality. This is the well-known "precautionary principle," which should be applied to policies on global warming but obviously isn't.

There are several things we need to know fast. The various global climate models show widely different results for some parts of the world, especially Amazonia. The Hadley Centre model, from the UK Meteorological Office, shows a complete catastrophe, with the Amazon forest being essentially wiped out by the year 2080 as a result of heat and drought (Cox et al., 2000, 2004). Several other models show a more modest but still serious drying in the Amazon, including the National Center for Atmospheric Research (NCAR) model from the USA and the Max Planck Institute model from Germany. Some others show little change, and one (the Geophysical Fluid Dynamics Laboratory model from the USA) even showed (as of the time of the 2007 IPCC report) an increase in Amazon rainfall (Kundzewicz et al., 2007, p. 183), but subsequent improvements in the model have eliminated this unrealistic behavior (Stephen M. Griffies, personal communication, 2009). Given the importance of the question of what happens to the Amazon rainforest, it is amazing that discrepancies of the magnitude still existing among models have not been resolved. The Hadley Centre results were first published in 2000 , and subsequent refinements of their model have only reinforced the catastrophic conclusion for Amazonia. Of the 21 models submitted to Phase 2 of the Coupled Model Intercomparison Project (CMIP2) (http://www.pcmdi.llnl. gov/CMIP); Covey et al. (2003) the HadCM3LC Hadley Centre model produced the best representation of the link between "El Niño-like conditions" and Amazon droughts (see Cox et al., 2004, p. 153). The Hadley Centre model is not perfect: it produces a present-day climate in Amazonia that is hotter (Cândido et al., 2007) and dryer (Huntingford et al., 2004) than the real climate. Establishment of a "permanent El Niño" indicated by the Hadley model is the key feature leading to the catastrophic result in Amazonia. However, the danger of savannization does not depend on the Hadley Centre model proving to be the best representation of future climate: an average of the results of 15 models indicates savannization of eastern Amazonia as a consequence of continued global warming (Salazar et al., 2007).

Linking El Niño to global warming has tremendous moral and political implications, in addition to the scientific ones. When El Nińo killed 200,000 people in Ethiopia in 1982 there was an enormous outpouring of charity and sympathy, with rock stars singing "We are the World" to attract donations for the victims. But the drought was presented as an act of God that was nobody's fault in particular. It wasn't your car or your deforestation that caused that disaster. But if the frequency of El Niño is linked to global warming, then everything changes because greenhouse-gas emissions have identifiable culprits. Contributions to global warming can be quantified and allotted to countries and individuals.

\section{2.) Biotic feedbacks}

There are several important features that were left out of the models used by the IPCC that need to be analyzed and included. One is the "biotic feedbacks," especially the carbon that would be released from the biomass and from the soil if the Amazon forest were to die and be replaced by grassland with scattered trees or, alternatively, by a low-biomass woody second growth. Only half a dozen of the over 20 models analyzed by the IPCC had the capability of simulating the biotic feedbacks, but these features were switched off in order to make the simulations of all models comparable. If these feedbacks are included the temperature in 2100 is $38 \%$ higher (Cox et al., 2004, p. 138). Amazonia is an important part of this effect.

Biotic feedbacks involve not only the carbon stock in forest biomass but also the stock in the soil under the forest. When forest is replaced by grass, whether through deforestation or climate-induced mortality, much of this soil stock is released (Fearnside and Barbosa, 1998). In fact, even without loss of the forest cover the increase in soil temperature from global warming has the potential to release massive amounts of carbon to the atmosphere, forming an additional positive feedback relationship with climate change (Fearnside, 2009a).

\section{3.) Climate sensitivity}

Another important topic is the matter of "climate sensitivity." This is the amount by which the average global temperature at equilibrium would increase over the preindustrial average with the concentration of atmospheric $\mathrm{CO}_{2}$ at double the pre-industrial level, a benchmark that would be crossed in approximately 2050 without mitigation. The "most probable" value for this is approximately $2.8^{\circ} \mathrm{C}$ and the assumption of climate sensitivity close to this value is the basis of all of the model runs that generated the graphs and maps in the IPCC report's summary for policy makers. The problem is that this "most probable" value for climate sensitivity implies that there is a $50 \%$ chance that the real value is higher than 
this, and it could be a lot higher. The point at which there is $95 \%$ assurance that the real value is included is now believed to be about $6.2^{\circ} \mathrm{C}$ according to a reassessment in 2006, down from a previous assessment that was substantially higher (Hegerl et al., 2006). There needs to be much more scientific work on constraining the estimates of climate sensitivity, and much more policy work on the implications of changes at the high end of the range.

The relevance of the more devastating results at the high end of the climate-sensitivity range can be visualized by an example. In 1998 the Palace II apartment building in Rio de Janeiro collapsed. For someone living in a building, the possibility that it might collapse represents a catastrophe. If someone who lives in an apartment building were to ask an engineer if the building will collapse and were to receive the answer that "it is most likely that the building will stay standing," would the apartment dweller be satisfied? This means that there may be a $51 \%$ chance that the building will stay standing, but there could be a $49 \%$ chance that it will collapse like the Palace II. The apartment dweller will therefore not be satisfied with a $50 \%$ probability of the building remaining standing, and will want an assurance of $99 \%$ or more. The same applies to the climate change scenarios based on a climate sensitivity value that represents the "most likely" outcome.

\section{C.) WHAT WE NEED TO NEGOTIATE}

The United Nations Framework Convention on Climate Change (UN-FCCC), better known as the "climate convention," specifies the purpose of the Convention as preventing the atmospheric concentrations of greenhouse gases from reaching levels that cause "dangerous interference with the global climate system" (UN-FCCC, 1992, Article 2). Negotiation of the definition of "dangerous interference" is currently underway.

The significance of defining a maximum increase in global temperature, and the corresponding permissible concentrations of greenhouse gases, is that the nations of the world must achieve this global target, and it no longer matters where the emissions are coming from. This gives Amazonia a substantial additional role in mitigating climate change. Not only does the forest have a role from the large annual emission provoked by deforestation, but the stock of carbon in the remaining forest has a value beyond its potential for future deforestation. The stock of carbon in the remaining forest could be released by climate change itself, and not only global climate change from the greenhouse effect but also partly from regional climate change resulting from loss of evapotranspiration as deforestation proceeds.

Due to the importance of the Amazonian forest to Brazil, it is very important that the country use its diplomatic weight to press for a very low value as the definition of this number. The definition of dangerous climatic change should be at the most $2^{\circ} \mathrm{C}$ above the pre-industrial level. This is the value chosen by the European Union as their definition of "dangerous" and is now endorsed by over 100 countries. Substantial uncertainty surrounds the equilibrium $\mathrm{CO}_{2}$ concentration to which this amount of warming corresponds, but it is in the neighborhood of $400 \mathrm{ppmv}$ of $\mathrm{CO}_{2}$ equivalent, including the effects of the trace gases such as methane and nitrous oxide. Since the concentration of $\mathrm{CO}_{2}$ alone is already at $387 \mathrm{ppmv}$ as of 2009, and the trace gases elevate the total effect to over $400 \mathrm{ppmv}$, the cuts in the global emissions will have to be very large and fast (Hare and Meinshausen, 2006). Therefore, all mitigation options need to be used, including both reduction in burning fossil fuels and decrease in deforestation.

The forest is already vulnerable, especially in the dryer areas near the eastern and southern edges of the forest (Hutyra et al., 2005; Salazar et al., 2007). Any further change in the direction expected from global warming increases the risk of savannization. Because of delays within the climate system, warming would continue for 20-30 years even if anthropogenic emissions were to halt immediately. After that period, however, the difference in simulated global temperatures is very great depending on what course emissions take over the coming years (e.g., IPCC, 2007b). The course of future emissions depends on international negotiations currently underway to define "dangerous interference with the global climate system."

The delays in the climate system mean that actions must be taken well before critical thresholds are passed. Because of the tremendous mass of the oceans (and because water vapor that evaporates is a greenhouse gas) the water continues to warm and affect climate even after emissions are reduced: the result of a kind "inertia." Controlling climate change is analogous to steering a large ship, which can take kilometers to change course after the helm is turned. In the case of the Titanic, the crew saw the iceberg before the ship hit it, but they couldn't get the ship to turn fast enough. In the case of climate, we may foresee a catastrophe occurring in model results after 2050, with the Amazon forest drying, but if we wait until the last minute to reduce emissions it will be too late.

\section{III.) MITIGATION BY AMAZON FOREST MAINTENANCE}

\section{A.) WAYS TO FIGHT GLOBAL WARMING IN AMAZONIA}

A wide variety of mitigation options has been proposed in Amazonia, including plantation silviculture (including charcoal production), agroforestry, forest management for timber, reduced-impact logging, soil carbon enhancement (including charcoal additions, no-till agriculture and pasture 
fertilization), and, most recently, biofuels (including oil palm). However, tapping the native forest's role in mitigation is by far the best both in terms of carbon benefits (Fearnside, 1995) and social and environmental concerns (Fearnside, 1996, 2006b). This discussion will be limited to the maintenance of standing forest.

Deforestation can be reduced by a variety of means, including command-and-control programs using inspections and fines, creation of protected areas of a variety of types (including "sustainable use" areas), various kinds of integrated development projects aimed at channeling labor and capital resources to sustainable land uses in deforested areas instead of clearing forest, direct payment for environmental services, and policy measures affecting infrastructure construction, agricultural credit, land-tenure and taxation. Environmental agencies such as the Brazilian Institute for the Environment and Renewable Natural Resources (IBAMA) only have access to some of these options, such as command-and-control measures, reserve creation and payment for environmental services.

It cannot be overemphasized that infrastructure decisions must be an integral part of efforts to control deforestation, rather than being separate as at present. Today major highways and other developments are, in practice, decided by decree based on political considerations, and the role of environmental agencies is restricted (in practice) to legalizing the construction process and suggesting small changes to minimize impacts. This must change such that a full evaluation of impacts, including resulting deforestation and climate impacts, are considered before decisions are made on building the infrastructure (e.g., Fearnside and Graça, 2006; Fearnside, 2007b). In order for the deforestation and emissions impacts of individual infrastructure decisions to be quantified (and, conversely, the benefits of the "no project" option), one must have deforestation models with realistic provisions for the stimulation effect of roads on deforestation and the percentage of "leakage" when deforestation is inhibited by reserves and other measures. "Leakage" refers to effects a mitigation project provokes outside of its boundaries that cancel out all or part of the climatic benefits of the project itself, for example if people who would have deforested in a protected areas simply move somewhere else in the forest and continue clearing. Existing models for regional deforestation (e.g., Soares-Filho et al., 2006) do not yet have this capability, but progress has been made towards enhancing these models to simulate the effects of individual decisions (Fearnside et al., 2009). This opens the possibility of much more effective proposals for capturing carbon credit through avoided deforestation, as well as providing a tool for improved decision-making on infrastructure.

\section{B.) BARRIERS TO REWARDING FOREST MAINTENANCE}

If keeping Amazonian forest standing is to assume a role in strategies to mitigate global warming one must look at what has so far prevented this from happening and then address these issues. The forest really has two separate roles with respect to global warming: the flow of carbon to the atmosphere represented by annual emissions from clearing (which can be reduced through avoided deforestation), and the stock of carbon in the standing forest. Deforestation activity in Amazonia is spatially highly concentrated, over $80 \%$ of it occurring in the "arc of deforestation" along the eastern and southern edges of the forest. In this area a system of rewarding avoided deforestation could be established where emissions are compared to a baseline (presumably based on the recent history of clearing). This is what is implied by the Kyoto Protocol under what is commonly known as "additionality," or what is additional as compared to what would have happened in the absence of a mitigation project. In parts of the region where little or no deforestation has taken place, a different system of rewarding environmental services is needed based on stocks. Clearly the role of the forest in mitigating global warming will only be tapped if the way that the reward is calculated for each location results in a reasonable return.

Brazil's diplomatic community has traditionally resisted the idea of rewarding the Amazon forest's climatic role under the UN-FCCC (e.g., CFR Independent Task Force. 2001; Fearnside, 2001). This has its root in a lack of confidence that Brazil's government is capable of controlling deforestation, the implication being that were Brazil to agree to reduce emissions by a given amount and then find that deforestation could not be reduced as promised, the country would (in the view of these people) be exposed to pressures that would interfere with Brazil's sovereignty in Amazonia. The solution to this is an unambiguous demonstration that the government can control deforestation if it is serious about doing so. Several lines of evidence indicate that the government has this ability (Fearnside, 2003; Fearnside and Barbosa, 2003).

A different set of concerns has been raised by various national governments and other entities that are committed to designing a system of mitigating global warming that is sufficiently reliable to be used as credit against emissions from fossil fuels. These include the level of uncertainty associated with each hectare of deforestation that is avoided and uncertainty as to how many hectares have been avoided (see Fearnside, 2000). Both require improvements of data and of monitoring capabilities. Much has improved in both respects. We at INPA have made significant progress in better quantifying the carbon stocks in the forests being cleared, in accounting for the emissions and uptakes that occur after clearing, and in modeling the process and distribution of deforestation. In addition, the large amounts of emission that 
can be avoided at relatively low cost mean that uncertainty can always be more than compensated for by granting less credit than the amount of physical emission believed to be avoided. In addition to these concerns over the data used in carbon accounting, there are also disagreements over the theoretical basis of the accounting itself, particularly with regard to "permanence" (the time the carbon remains out of the atmosphere), or more generally the value attributed to time (Fearnside, 2002a, 2002b; Fearnside et al., 2000) and leakage (Fearnside, 2009b). Several proposals exist to address these problems, including proposals generated at INPA. Lastly, negotiations for rewarding environmental services must address the question of what is to be done with the money such that it ensures attainment of both objectives: maintaining the forest with its environmental services and maintaining the wellbeing of the human population in the Amazonian interior.

\section{C.) BRAZIL MUST ASSUME LEADERSHIP}

Brazil is one of the countries of the world with the greatest expected impacts from global warming (Dias et al., 2007; Fearnside, 2008d; Magrin et al., 2007). In addition to massive mortality of the Amazonian forest, other parts of the country would also be affected. In the Northeast global warming would cause drying in an area that already suffers constantly from lack of rain. In the South it would increase torrential rain events and typhoons. Sea-level rise affects the entire coast where much of the country's population lives.

Brazil must make a quantitative commitment to reduce deforestation. It is important that this be under the climate convention, as opposed to internal commitments that might be rewarded through voluntary funds outside of the Kyoto process, as proposed by Brazil at the conferences of the parties in Nairobi, Bali and Poznan in 2006, 2007 and 2008 (e.g., Brazil, 2006; Brazil, Comitê Interministerial sobre Mudança do Clima, 2008). If the industrialized countries decide to fight global warming in a serious way, agreeing in large cuts in their emissions under the climate convention, all of their resources will be used to meet their negotiated targets and nothing will remain for voluntary funds.

At the United Nations meeting on climate change, held in Vienna in August 2007, the Brazilian representative repeated the country's position since the 1992 "Earth Summit" (ECO92) of avoiding any quantitative commitment regarding emissions (O Estado de São Paulo, 2007). Undoubtedly, Brazil can choose to continue to resist taking on a commitment for a few more years, but sooner or later it will be forced to make a commitment if global warming is to be controlled. It is in Brazil's national interest that such a change of position be made now rather than later. Brazil must assume the leadership in the fight against global warming.

\section{ACKNOWLEDGEMENTS}

The Conselho Nacional do Desenvolvimento Científico e Tecnológico (CNPq: Proc. 306031/2004-3, 557152/2005-4, 420199/2005-5, 474548/2006-6), Rede GEOMA and Instituto Nacional de Pesquisas da Amazônia (INPA: PRJ05.57) contributed financial support. The portion of this text on mitigation was presented as a discussion paper for INPA's Grupo de Estudos Estratégicos Amazônicos (GEEA).

\section{LITERATURE CITED}

Allen, M.R.; Frame; D.J.; Huntingford, C.; Jones, C.D.; Lowe, J.A.; Meinshausen, M.; Meinshausen, N. 2009. Warming caused by cumulative carbon emissions towards the trillionth tonne. Nature, 458: 1163-1166.

Brazil. 2006. The 12th Conference of the Parties of the UNFCCC, Nairobi, Kenya. Positive incentives for voluntary action in developing countries to address climate change: Brazilian perspective on reducing emissions from deforestation. United Nations Framework Convention on Climate Change (UNFCCC), Bonn, Germany. 4 pp. (Available at: http://unfccc. int/files/meetings/dialogue/application/pdf/wp_21_braz.pdf).

Brazil, Comitê Interministerial sobre Mudança do Clima. 2008. Plano Nacional sobre Mudança do Clima - PNMC -- Brasil. Ministério do Meio Ambiente, Brasília, DF, Brazil. 129 pp. (Available at: http://www.mma.gov.br/estruturas/imprensa/_ arquivos/96_01122008060233.pdf)

Brazil, INPE (Instituto Nacional de Pesquisas Espaciais). 2009. Projeto PRODES: Monitoramento da Floresta Amazônica Brasileira por Satélite. INPE, São José dos Campos, São Paulo, Brazil. (Available at: http://www.obt.inpe.br/prodes/).

Brown, I.F.; Schroeder, W.; Setzer, A.; Maldonado, M.J.R.; Pantoja, N.; Duarte, A.F.; Marengo, J. 2006. Monitoring fires in Southwestern Amazonia rain forest. EOS, Transactions of the American Geophysical Union, 87(26): 253-264.

Cândido, L.A.; Manzi, A.O.; Tota, J.; da Silva, P.R.T.; da Silva, F.S.M.; dos Santos, R.N.N.; Correia, F.W.S. 2007. O Clima atual e futuro da Amazônia nos cenários do IPCC: A questão da savanização. Ciência e Cultura, 59(3): 44-47.

CFR Independent Task Force. 2001. A letter to the President and a memorandum on U.S. policy toward Brazil. Council on Foreign Relations (CFR), New York, U.S.A. 13 pp. (Available at: http:// www.cfr.org).

Covey, C.; AchutaRao, K.M.; Cubasch, U.; Jones, P.; Lambert, S.J.; Mann, M.E.; Phillips, T.J. Taylor, K.E. 2003. An overview of results from the Coupled Model Intercomparison Project. Global and Planetary Change, 37: 103-133.

Cox, P.M.; Betts, R.A.; Jones, C.D.; Spall, S.A.; Totterdell, I.J. 2000. Acceleration of global warming due to carbon-cycle feedbacks in a coupled climate model. Nature, 408: 184-187.

Cox, P.M.; Betts, R.A.; Collins, M.; Harris, P.P.; Huntingford, C.; Jones, C.D. 2004. Amazonian forest dieback under climatecarbon cycle projections for the 21 st century. Theoretical and 
Applied Climatology, 78: 137-156, doi:10.1007/s00704-0040049-4.

Cox, P.M.; Harris, P.P.; Huntingford, C.; Betts, R.A.; Collins, M.; Jones, C.D.; Jupp, T.E;. Marengo, J.A.; Nobre, C.A. 2008. Increasing risk of Amazonian drought due to decreasing aerosol pollution. Nature, 453: 212-215.

Dias, P.L.S.; Ribeiro, W.C.; Nunes, L.H. (Eds.). 2007. A Contribution to Understanding the Regional Impacts of Global Change in South America. Instituto de Estudos Avançados, Universidade de São Paulo, São Paulo, Brazil. 418 pp.

O Estado de São Paulo. 2007. "Brasil diz que combate efeito estufa, mas não aceita metas” 27 August 2007. (Available at: http:// www.estadao.com.br/vidae/not_vid41671,0.htm).

Fearnside, P.M. 1985. Environmental change and deforestation in the Brazilian Amazon. In: Hemming, J. (Ed.) Change in the Amazon Basin: Man's Impact on Forests and Rivers. Manchester University Press, Manchester, U.K. pp. 70-89.

Fearnside, P.M. 1995. Global warming response options in Brazil's forest sector: Comparison of project-level costs and benefits. Biomass and Bioenergy, 8: 309-322.

Fearnside, P.M. 1996. Socio-economic factors in the management of tropical forests for carbon. In: Apps, M.J.; Price, D.T. (Eds.). Forest Ecosystems, Forest Management and the Global Carbon Cycle. NATO ASI Series, Subseries I "Global Environmental Change," Vol. 40. Springer-Verlag, Heidelberg, Germany. pp. 349-361.

Fearnside, P.M. 1997. Limiting factors for development of agriculture and ranching in Brazilian Amazonia. Revista Brasileira de Biologia, 57(4): 531-549.

Fearnside, P.M. 2000. Uncertainty in land-use change and forestry sector mitigation options for global warming: Plantation silviculture versus avoided deforestation. Biomass and Bioenergy, 18: 457-468.

Fearnside, P.M. 2001. Saving tropical forests as a global warming countermeasure: An issue that divides the environmental movement. Ecological Economics, 39: 167-184.

Fearnside, P.M. 2002a. Why a 100-year time horizon should be used for global warming mitigation calculations. Mitigation and Adaptation Strategies for Global Change, 7: 19-30.

Fearnside, P.M. 2002b. Time preference in global warming calculations: A proposal for a unified index. Ecological Economics, 41: 21-31.

Fearnside, P.M. 2003. Deforestation control in Mato Grosso: A new model for slowing the loss of Brazil's Amazon forest. Ambio, 32: 343-345.

Fearnside, P.M. 2006a. A vazante na Amazônia e o aquecimento global. Ciência Hoje, 38(231): 76-78.

Fearnside, P.M. 2006b. Mitigation of climatic change in the Amazon. In: Laurance, W.F.; Peres, C.A. (Eds.) Emerging Threats to Tropical Forests. University of Chicago Press, Chicago, Illinois, U.S.A., pp. 353-375.

Fearnside, P.M. 2007a. Uso da terra na Amazônia e as mudanças climáticas globais. Brazilian Journal of Ecology, 10: 83-100.
Fearnside, P.M. 2007b. Brazil's Cuiabá-Santarém (BR-163) Highway: The environmental cost of paving a soybean corridor through the Amazon. Environmental Management, 39: 601-614.

Fearnside, P.M. 2008a. Quantificação do serviço ambiental do carbono nas florestas amazônicas brasileiras. Oecologia Brasiliensis, 12: 743-756.

Fearnside, P.M. 2008b. Deforestation in Brazilian Amazonia and global warming. Annals of Arid Zone, 47(3-4): 1-20. (in press).

Fearnside, P.M. 2008c. Amazon forest maintenance as a source of environmental services. Anais da Academia Brasileira de Ciência, 80: 101-114.

Fearnside, P.M. 2008d. Mudanças climáticas globais e a floresta amazônica. In: Buckeridge, M.S. (Ed.) Biologia e Mudanças Climáticas Globais no Brasil. RiMa Editora, São Paulo, Brazil, pp. 131-150.

Fearnside, P.M. 2009a. Estoque e estabilidade do carbono nos solos na Amazônia brasileira. In: Teixeira, W.G.; Madari, B.E.; Benites, V.M.; Kern, D.C.; Falcão, N.P.S. (Eds.) As Terras Pretas de Índio: Caracterização e manejo para formação de novas áreas. Empresa Brasileira de Pesquisa Agropecuária (EMBRAPA) Amazônia Ocidental, Belém, Pará, Brazil. pp. 259-262.

Fearnside, P.M. 2009b. Carbon benefits from Amazonian forest reserves: Leakage accounting and the value of time. Mitigation and Adaptation Strategies for Global Change. 14(6): 557-567.

Fearnside, P.M.; Barbosa, R.I. 1998. Soil carbon changes from conversion of forest to pasture in Brazilian Amazonia. Forest Ecology and Management, 108: 147-166.

Fearnside, P.M.; Barbosa, R.I. 2003. Avoided deforestation in Amazonia as a global warming mitigation measure: The case of Mato Grosso. World Resource Review, 15: 352-361.

Fearnside, P.M.; Graça, P.M.L.A. 2006. BR-319: Brazil's ManausPorto Velho Highway and the potential impact of linking the arc of deforestation to central Amazonia. Environmental Management, 38: 705-716.

Fearnside, P.M.; Graça, P.M.L.A.; Keizer, E.W.H.; Maldonado, F.D.; Barbosa, R.I.; Nogueira, E.M. 2009. Modelagem de desmatamento e emissóes de gases de efeito estufa na região sob influência da Rodovia Manaus-Porto Velho (BR-319). Revista Brasileira de Meteorologia, 24(2): 208-233.

Fearnside, P.M.; Lashof, D.A.; Moura-Costa, P. 2000. Accounting for time in mitigating global warming through land-use change and forestry. Mitigation and Adaptation Strategies for Global Change, 5: 239-270.

Folha de São Paulo. 2007. "Conclusão de texto involve debate intenso”, 6 April 2007, p. A-14.

Hare, B.; Meinshausen, M. 2006. How much warming are we committed to and how much can be avoided? Climatic Change, 75: 111-149.

Hegerl, G.C.; Crowley, T.J.; Hyde, W.T.; Frame, D.J. 2006. Climate sensitivity constrained by temperature reconstructions over the past seven centuries. Nature, 440: 1029-1032.

Huntingford, C.; Harris, P.O.; Gedney, N.; Cox, P.M.; Betts, R.A.; Marengo, J.A.; Gash, J.H.C. 2004. Using a GCM analogue 
model to investigate the potential for Amazonian forest dieback. Theoretical and Applied Climatology, 78: 177-185.

Hutyra, L.R.; Munger, J.W.; Nobre, C.A.; Saleska, S.R.; Vieira, S.A.; Wofsy, S.C. 2005. Climatic variability and vegetation vulnerability in Amazonia. Geophysical Research Letters, 32: L24712, doi:10.1029/2005GL024981.

IPCC (Intergovernmental Panel on Climate Change). 2007a. Summary for policymakers. In: Parry, M.L.; Canziani, O.F.; Palutikof, J.P.; van der Linden, P.J.; Hanson, C.E. (Eds.). Climate Change 2007: Impacts, Adaptation and Vulnerability. Contribution of Working Group II to the Fourth Assessment Report of the Intergovernmental Panel on Climate Change, Cambridge University Press, Cambridge, U.K., pp. 7-22.

IPCC (Intergovernmental Panel on Climate Change). 2007b. Summary for policymakers. In: Solomon, S.; Qin, D.; Manning, M.; Chen, Z.; Marquis, M.; Averyt, K.B.; Tignor, M. Miller, H.L. (Eds.). Climate Change 2007: The Physical Science Basis. Contribution of Working Group I to the Fourth Assessment Report of the Intergovernmental Panel on Climate Change, Cambridge University Press, Cambridge, U.K., pp 1-18.

Kundzewicz, Z.W.; Mata, L.J.; Arnell, N.W.; Döll, P.; Kabat, P.; Jiménez, B.; Miller, K.A;. Oki, T.; Sen, Z.; Shiklomanov, I.A. 2007: Freshwater resources and their management. In: Parry, M.L.; Canziani, O.F.; Palutikof, J.P.; van der Linden, P.J.; Hanson, C.E. (Eds.). Climate Change 2007: Impacts, Adaptation and Vulnerability. Contribution of Working Group II to the Fourth Assessment Report of the Intergovernmental Panel on Climate Change, Cambridge University Press, Cambridge, U.K., pp. 173-210.

Laurance, W.F.; Nascimento, H.E.M.; Laurance, S.G.; Andrade, A.; Ribeiro, J.E.L.S.; Giraldo, J.P.; Lovejoy, T.E.; Condit, R.; Chave, J.; Harms, K.E.; D’Angelo, S. 2006. Rapid decay of tree-community composition in Amazonian forest fragments. Proceedings of the National Academy of Sciences, 103(50): 19010-19014.

Magrin, G.; Gay García, C.; Cruz Choque, D.; Giménez, J.C.; Moreno, A.R.; Nagy, G.J.; Nobre, C.; Villamizar, A. 2007. Latin America. In: Parry, M.L.; Canziani, O.F.; Palutikof, J.P.; van der Linden, P.J.; Hanson, C.E. (Eds.) Climate Change 2007: Impacts, Adaptation and Vulnerability. Contribution of Working Group II to the Fourth Assessment Report of the Intergovernmental Panel on Climate Change, Cambridge University Press, Cambridge, U.K., pp. 581-615.

Marengo, J.A.;. Nobre, C.A.; Tomasella, J.;. Oyama, M.D.; Sampaio de Oliveira, G.; de Oliveira, R.; Camargo, H.; Alves, L.M.; Brown, I.F. 2008. The drought of Amazonia in 2005. Journal of Climate, 21: 495-516.

Meehl, G.A.; Stocker, T F.; Collins, W.D.; Friedlingstein, P.; Gaye, A.T.; Gregory, J M.; Kitoh, A.; Knutti, R.; Murphy J M.; Noda, A.; Raper, S.C B.; Watterson, I.G. ; Weaver, A.J.; Zhao, Z-C. 2007. Global Climate Projections. In: Solomon, S.; Qin, D.; Manning, M.; Chen, Z.; Marquis, M.; Averyt,_K.B.; Tignor, M.; Miller, H.L. (Eds.). Climate Change 2007: The Physical Science Basis. Contribution of Working Group I to the Fourth Assessment Report of the Intergovernmental Panel on Climate Change, Cambridge University Press, Cambridge, U.K., pp. 247-845.
Meinshausen, M.; Meinshausen, N.; Hare, W.; Raper, S.C.B.; Frieler, K.; Knutti, R.; Frame, D.J.; Allen, M.R. 2009. Greenhouse-gas emission targets for limiting global warming to $2^{\circ} \mathrm{C}$. Nature, 458 : 1158-1162.

Nascimento, H.E.M.; Laurance, W.F. 2004. Biomass dynamics in Amazonian forest fragments. Ecological Applications, 14(4) Supplement: S127-S138.

Nepstad, D.C.; Alencar, A; Nobre, C.; Lima, E; Lefebvre, P.; Schlesinger, P.; Potter, C.; Moutinho, P.; Mendoza, E.; Cochrane, M.; Brooks, V. 1999. Large-scale impoverishment of Amazonian forests by logging and fire. Nature, 398: 505-508.

Nepstad, D.C.; Carvalho, G.; Barros, A.C.; Alencar, A.; Capobianco, J.P.; Bishop, J.; Moutinho, P.; Lefebvre, P.; Silva, Jr., U.L.; Prins, E. 2001. Road paving, fire regime feedbacks, and the future of Amazon forests. Forest Ecology and Management, 154: 395-407.

Nepstad, D.C.; Tohver, I.M.; Ray, D.; Moutinho, P.; Cardinot, G. 2007. Mortality of large trees and lianas following experimental drought in an Amazon forest. Ecology, 88: 2259-2269.

Phillips, O.L. and 65 others. 2009. Drought sensitivity of the Amazon rainforest. Science, 323: 1344-1347.

Salazar, L.F.; Nobre, C.A.; Oyama, M.D. 2007. Climate change consequences on the biome distribution in tropical South America. Geophysical Research Letters, 34: L09708, doi:10.1029/2007GL029695.

Sampaio, G.; Nobre, C.; Costa, M.H.; Satyamurty, P.; SoaresFilho, B.S.; Cardoso, M. 2007. Regional climate change over eastern Amazonia caused by pasture and soybean cropland expansion. Geophysical Research Letters, 34: L17709, doi:10.1029/2007GL030612.

Soares-Filho B.S.; Nepstad, D.C.; Curran, L.M.; Cerqueira, G.C.; Garcia, R.A.; Ramos, C.A.; Voll, E.; McDonald, A.; Lefebvre, P.; Schlesinger, P. 2006. Modelling conservation in the Amazon Basin. Nature, 440: 520-523.

Trenberth, K.E.; Shea, D.J. 2006. Atlantic hurricanes and natural variability in 2005. Geophysical Research Letters, 33: L12704, doi:10.1029/2006GL026894.

UN-FCCC (United Nations Framework Convention on Climate Change). 1992. United Nations Framework Convention on Climate Change. (Available in English at: http://www.unfccc.de and in Portuguese at: http://www.mct.gov.br).

Vasconcelos, S.S.; Brown, I.F. 2007. The use of hot pixels as an indicator of fires in the MAP region: Tendencies in recent years in Acre, Brazil. In: Epiphanio, J.C.N.; Galvão, L.S.; Fonseca, L.M.G. (Eds.) Anais XIII Simpósio Brasileiro de Sensoriamento Remoto, Florianópolis, Brasil 21-26 abril 2007. Instituto Nacional de Pesquisas Espaciais (INPE), São José dos Campos, São Paulo, Brazil. pp. 4549-4556.

Recebido em 26/11/2007

Aceito em 16/06/2009 
